УДК 591.1

https://doi.org/10.32634/0869-8155-2021-348-4-17-20

Краткий обзор/Brief review

Прохорова Т.M.,

Попова Э.В.,

Гуркина О.А.,

Смутнев П.В.,

Рубанова М.Е.

ФГБОУ ВО «Саратовский государственный аграрный университет имени Н.И. Вавилова», Россия, 410012, г. Саратов, Театральная пл., 1

E-mail: prokhorovatm@yandex.ru, elina-popova-00@mail.ru,gurkinaoa@yandex.ru, smutnev-asd@yandex.ru,mariru65@yandex.ru

Ключевые слова: печень, гепатит, билирубин, Оксиметилурацил, Легалон, перекисное окисление липидов, крыса

Для цитирования: Прохорова Т.М., Попова Э.В., Гуркина О.А., Смутнев П.В., Рубанова М.Е. Гепатопротекторное действие оксиметилурацила при экспериментальном токсическом гепатите. Аграрная наука. 2021; 348 (4): 17-20.

https://doi.org/10.32634/0869-8155-2021-348-4-17-20

Конфликт интересов отсутствует

Tatiana M. Prokhorova,

Elina V. Popova,

Oksana A. Gurkina,

Peter V. Smutnev,

Marina E. Rubanova

Saratov State Agrarian University named after N.I. Vavilov, Teatralnaya pl., 1, Saratov, 410012 , Russia

E-mail: prokhorovatm@yandex.ru,

elina-popova-00@mail.ru, gurkinaoa@yandex.ru, smutnev-asd@yandex.ru,mariru65@yandex.ru

Key words: liver, hepatitis, bilirubin, Oxymethyluracil, Legalon, lipid peroxidation rat

For citation: Prokhorova T.M., Popova E.V., Gurkina O.A., Smutnev P.V., Rubanova M.E. Hepatoprotective effect of Oxymethyluracil on experimental toxic hepatitis. Agrarian Science. 2021; 348 (4): 17-20. (In Russ.)

https://doi.org/10.32634/0869-8155-2021-348-4-17-20

There is no conflict of interests
Гепатопротекторное действие Оксиметилурацила при экспериментальном

\section{токсическом гепатите}

\section{PEЗЮME}

В статье изложены результаты исследования препарата Оксиметилурацил при токсическом поражении печени тетрахлорметаном. В результате вызванного токсического гепатита у лабораторных крыс наблюдается сбой в работе системь свободнорадикального окисления липидов: повышается содержание диеновых конъюгатов в 1,93 раза и малонового диальдегида - 1,8 раза в сыворотке крови по сравнению с интактной группой. Происходит изменение показателей пигментообразования печени: показатели общего билирубина увеличились в 3,06 раза, прямого билирубина - в 5,63 раза, непрямого билирубина - в 2,8 раза по сравнению с контрольной группой. После лечебной терапии препаратами Легалон и Оксиметилурацил ингибируется перекисное окисление липидов и повышается антиоксидантный статус организма, наблюдается улучшение показателей билирубина. При сравнении гепатопротекторных свойств препаратов в условиях поражения печени тетрахлорметаном применение Оксиметилурацила менее эффективно, чем Легалона.

\section{Hepatoprotective effect of Oxymethyluracil on experimental toxic hepatitis}

\section{ABSTRACT}

The article presents the results of a study of Oxymethyluracil effect on toxic liver damage with carbon tetrachloride. As a result of the induced toxic hepatitis in laboratory rats, a malfunction of the free radical lipid oxidation system is observed: the content of diene conjugates increases by 1.93 times and malondialdehyde - by 1.8 times in the blood serum compared to the intact group. There is a change in the indicators of liver pigmentation: the indicators of total bilirubin increased by 3.06 times, direct bilirubin - by 5.63 times, indirect bilirubin - by 2.8 times compared to the control group. After therapy with Legalon and Oxymethyluracil lipid peroxidation is inhibited and the antioxidant status of the body increases, and bilirubin indicators improve. When comparing the hepatoprotective properties of drugs in conditions of liver damage with carbon tetrachloride, the use of Oxymethyluracil is less effective than Legalon. 


\section{Введение}

В настоящее время токсические поражения печени являются одной из актуальных проблем современной медицины. Несмотря на большой арсенал гепатопротекторов, не всегда удается добиться повышения регенераторной активности печени и стабилизации течения гепатита. В развитии патологического процесса при токсическом гепатите большое значение имеют нарушения процессов перекисного окисления липидов (ПОЛ) и антиоксидантной системы (АОС). Одним из универсальных механизмов повреждения клеток является чрезмерная пероксидация мембранных структур, которая обусловлена усиленной выработкой активных форм кислорода. Поэтому при токсических поражениях печени, прежде всего, применяют антиоксидантную терапию, направленную на ограничение поЛ и стабилизацию мембран. В связи с этим внимание ученых, занимающихся разработкой новых гепатопротекторов, привлечено к соединениям с выраженной антиоксидантной активностью [1].

При тетрахлорметановой модели повреждения печени инциируется образование трихлорметильных радикалов и активных форм кислорода, которые приводят к истощению антиоксидантной защиты и вторично приводят к воспалению. Таким образом, для защиты печени при тетрахлорметановой интоксикации важны антиоксидантные и противовоспалительные свойства препаратов [2]

Оксиметилурацил является антиоксидантом, ингибирующим процессы перекисного окисления липидов, он стабилизирует мембраны клеток и органелл, стимулирует регенераторные процессы [3].

Исходя из вышеизложенного, целью исследования явилось изучение изменения антиоксидантных показателей и билирубина при коррекции препаратом Оксиметилурацил в сравнении с препаратом Легалон при тетрахлорметановой модели токсического повреждения печени.

\section{Материалы и методы исследований}

Экспериментальная часть исследования проводилась в лаборатории кафедры «Морфология, патология животных и биология» ФГБОУ ВО СГАУ им. Н.И. Вавилова. Объектом исследования были самцы белых крыс весом 180-200 г в возрасте 3-4 месяцев. Животные были разделены на 4 подопытные группы, по 8 животных в каждой группе. Исследования проводились в соответствии с Европейской директивой по защите животных, используемых в научных целях [4]. Животные содержались в виварии на стандартном рационе.

Токсический гепатит вызывали путем внутрибрюшинного введения 50\%-ого раствора тетрахлорметана $\left(\mathrm{CCl}_{4}\right)$ на оливковом масле из расчета 1 мл на кг массы тела два раза в неделю в течение 20 дней. Коррекцию токсического поражения печени, вызванного тетрахлорметаном, проводили препаратом Оксиметилурацил, в качестве препарата сравнения использовали препарат Легалон, препараты вводили перорально в дозе 50 мг на кг массы тела.

Состояние антиоксидантной защиты оценивали по каталазной активности сыворотки крови. Каталазную активность сыворотки крови крыс определяли по методу М.А. Королюка и др [5]. Интенсивность процессов перекисного окисления липидов оценивали по содержанию диеновых конъюгатов (ДК) в сыворотке крови. Определение диеновых коньюгатов (ДК) в сыворотке крови определяли спектрометрическим методом [6]. Определение содержания малонового диальдегида проводили тиобарбитуровым методом [7].

Исследование показателей билирубина проводили с помощью набора реагентов фирмы «Диакон-ДС» [8].

Статистическая обработка полученных данных проводилась с с использованием программы вариационной статистики Microsoft Excel.

\section{Результаты исследований и их обсуждение}

На первом этапе исследовали влияние препаратов Легалон и Оксиметилурацил на антиоксидантные показатели сыворотки крови при токсическом поражении печени. Результаты представлены в таблице 1.

Перекисное окисление липидов (ПОЛ) - один из наиболее важных окислительных процессов в организме, который является основной причиной повреждения клеточных мембран. Одним из продуктов перекисного окисления являются диеновые конъюгаты $[9,10]$.

Исходная концентрация диеновых коньюгатов в сыворотке крови составила у контрольной группы 8,26 $\pm 1,05$ мкмоль/мл. После введения тетрахлорметана содержание в сыворотке крови диеновых коньюгатов увеличилось в 1,93 раза (15,93 $\pm 0,95$ мкмоль/мл) по сравнению с контролем. Повышенная концентрация диеновых коньюгатов в сыворотке крови свидетельствует о патологических процессах в организме, так как распад диеновых коньюгатов приводит к образованию вторичных продуктов перекисного окисления липидов, тем самым вызывая дальнейшую стимуляцию процессов свободнорадикального окисления. После коррекции токсического поражения печени препаратами Легалон и Оксиметилурацил наблюдали снижение уровня диеновых коньюгатов: на 30 и 23\% после препарата Легалон и Оксиметилурацил соответственно. Это свидетельствует, что данные препараты ингибируют перекисное окисление липидов.

Также в процессе перекисного окисления липидов образуется малоновый диальдегид (МДА), накопление которого отражает степень оксидативного стресса в организме [9, 10]. Оценка этого показателя выявила, что концентрация МДА у опытной группы 2 с вызванным

\section{Таблица 1. Влияние препаратов Легалон и Оксиметилурацил на антиоксидантные показатели сыворотки крови при токсическом поражении печени $(M \pm m)$}

Table 1. Effect of the drugs Legalon and Oxymethyluracil on the antioxidant parameters of blood serum in toxic liver damage ( $M \pm m$ )

\begin{tabular}{|c|c|c|c|c|}
\hline Показатель & $\begin{array}{c}\text { Опытная группа } 1 \\
\text { (контрольная группа) }\end{array}$ & $\begin{array}{c}\text { Опытная группа } 2 \\
\left(50 \% \text {-ный раствор } \mathrm{CCl}_{4}\right)\end{array}$ & $\begin{array}{c}\text { Опытная группа } 3 \\
\text { (Легалон) }\end{array}$ & $\begin{array}{c}\text { Опытная группа } 4 \\
\text { (Оксиметилурацил) }\end{array}$ \\
\hline ДК (нмоль/мл) & $8,26 \pm 1,05$ & $15,93 \pm 0,95^{\star}$ & $11,18 \pm 6,1^{\star}$ & $12,23 \pm 6,14^{\star}$ \\
\hline МДА (ммоль/л) & $7,95 \pm 0,88$ & $14,53 \pm 0,26^{\star}$ & $10,03 \pm 0.13^{*}$ & $11,48 \pm 0,25^{\star}$ \\
\hline Каталаза (ммоль/л) & $17,93 \pm 0,53$ & $36,55 \pm 1,94^{\star}$ & $21,8 \pm 0,18^{\star}$ & $24,94 \pm 0,56^{\star}$ \\
\hline
\end{tabular}


Таблица 2. Показатели содержания билирубина в сыворотке крови белых крыс при моделировании токсического гепатита (мкмоль/л)

Table 2. Indicators of bilirubin content in the blood serum of white rats in the simulation of toxic hepatitis (mmol/l)

\begin{tabular}{|l|c|c|c|c|}
\hline Показатель & $\begin{array}{c}\text { Опытная группа 1 } \\
\text { (контрольная группа) }\end{array}$ & $\begin{array}{c}\text { Опытная группа 2 } \\
\text { (50\%-ный раствор ССI }\end{array}$ & $\begin{array}{c}\text { Опытная группа 3 } \\
\text { (Легалон) }\end{array}$ & $\begin{array}{c}\text { Опытная группа 4 } \\
\text { (Оксиметилурацил) }\end{array}$ \\
\hline ий билирубин & $6,13 \pm 0,33$ & $18,78 \pm 2,57^{\star}$ & $10,68 \pm 0,24^{\star}$ & $13,24 \pm 0,42^{\star}$ \\
\hline ой билирубин & $0,58 \pm 0,04$ & $3,27 \pm 0,08^{\star}$ & $0,94 \pm 0,03^{\star}$ & $0,98 \pm 0,05^{\star}$ \\
\hline 0,050 & $5,55 \pm 0,23$ & $15,51 \pm 0,42^{\star}$ & $9,74 \pm 0,15^{\star}$ & $12,26 \pm 0,42^{\star}$ \\
\hline
\end{tabular}

токсическим гепатитом повысилась в 1,8 раза по сравнению с контролем. Высокий уровень МДА в сыворотке крови свидетельствует об активности патологического процесса и рассматривается как компенсаторная реакция защиты организма. После коррекции препаратами Легалон и Оксиметилурацил наблюдали снижение концентрации малонового диальдегида в сыворотке крови: на 31 и 21\% после препаратов Легалон и Оксиметилурацил соответственно.

При изучении активности каталазы было выявлено, что показатели каталазы у группы с токсическим повреждением печени повысились в 2,04 раза по сравнению с контролем. Функция каталазы заключается в защите организма от активных кислородсодержащих радикалов и перекиси водорода. После коррекции препаратами Легалон и Оксиметилурацил наблюдали снижение активности каталазы в сыворотке крови: на 40,2 и 31,8\% после препаратов Легалон и Оксиметилурацил соответственно.

На следующем этапе исследования было проведено изучение показателей билирубина у опытных групп. Результаты исследования представлены в таблице 2.

При поражениях печени в гепатоцитах нарушается процесс конъюгации билирубина с глюкуроновой кислотой, что связано с некрозом печеночных клеток, закупоркой внутрипеченочных желчных канальцев густой желчью. Это ведет к повышению уровня связанного билирубина в крови.

Анализ данных, полученных в результате исследования, показал, что показатели общего билирубина у опытной группы 2 увеличились в 3,06 раза по сравнению с контрольной группой, средняя концентрация прямого билирубина повысилась в 5,63 раза, а непрямого били-

\section{ЛИТЕРАTУPA /REFERENCES}

1. Баркова Д. А., Пудовкин Н.А., Салаутин В.В. Особенности свободно-радикального окисления липидов при хроническом циррозе печени//Ученые записки Казанской государственной академии ветеринарной медицины им. Н.Э. Баумана, 2018, T. 234. №2, C.40-44. Barkova D. A., Pudovkin N. A., Salautin V. V. Features of free radical lipid oxidation in chronic liver cirrhosis//Scientific notes of the Kazan State Academy of Veterinary Medicine named after N. E. Bauman, 2018, vol. 234. No. 2, p. 40-44.

2. Скупневский С.В., Кабоева Б.Н., Батагова Ф.Э., Джиоев И.Г. Влияние сезонных биоритмов на перекисное окисление липидов у крыс с интоксикацией тетрахлорметаном// Международный журнал прикладных и фундаментальных исследований, 2014, № 11-5, C.843-846. Skupnevsky S. V., Kaboeva B. N., Batagova F. E., Dzhioev I. G. Influence of seasonal biorhythms on lipid peroxidation in rats with carbon tetrachloride intoxication// International Journal of Applied and Fundamental Research, 2014, no. $11-5$, pp. $843-846$

3. Мышкин В.А., Еникеев Д.А. Оксиметилурацил и патология печени: экспериментальный аспект //Медицинский вест- рубина - в 2,8 раза. После проведения лечебной терапии препаратами Легалон и Оксиметилурацил наблюдалось снижение показателей билирубина: показатели уровня общего билирубина снизились на $75 \%$ после препарата Легалон и на 30\% - после препарата Оксиметилурацил, средняя концентрация прямого билирубина понизилась на 71 и 70\%, а средняя концентрация непрямого билирубина - на 37 и $21 \%$ после препаратов Легалон и Оксиметилурацил соответственно.

\section{Выводы}

Таким образом, после вызванного экспериментального токсического гепатита у лабораторных крыс наблюдается сбой в работе системы свободнорадикального окисления липидов. В организме наблюдается повышение содержания диеновых конъюгатов и малонового диальдегида, что свидетельствует об активности патологического процесса и рассматривается как компенсаторная реакция защиты организма. Курсовое введение препаратов Легалон и Оксиметилурацил ингибировало перекисное окисление липидов и повысило антиоксидантный статус организма при экспериментальном токсическом гепатите. В результате хронического токсического повреждения печени, вызванного тетрахлорметаном, происходит изменение показателей пигментообразования печени. После лечебной терапии препаратами Легалон и Оксиметилурацил наблюдалось улучшение показателей билирубина вследствие снижения токсического эффекта, но в результате исследования было выявлено, что при сравнении гепатопротекторных свойств препаратов в условиях поражения печени тетрахлорметаном применение Оксиметилурацила менее эффективно, чем Легалона.

ник Башкортостана, 2009, T.4, №2, C. 147-151. Myshkin V. A. Enikeev D. A. Oxymethyluracil and liver pathology: experimental aspect / / Medical Bulletin of Bashkortostan, 2009, vol. 4, no. 2, pp. 147-151.

4. Directive 2010/63/EU of the European Parliament and of the Council of 22 September 2010 on the protection of animals used for scientific purposes (Text with EEA relevance): European Commission: Brussels. 2010.

5. Королюк, М.А. Метод определения активности каталазь [Текст] / М.А. Королюк, Л.И. Иванова, И.Г. Майорова т др. // Лабораторное дело. - 1988. - №1. - С. 16-194. Koroljuk M.A. Metod opredelenija aktivnosti katalazy / M.A. Koroljuk, L.I. Ivanova, I.N. Majorova // Laboratornoe delo. 1988. no . pp. 16-18.

6. Стальная И.Д., Гаришвили Т.Г. Методы определения диеновой коньюгации ненасыщенных высших жирных кислот / И.Д. Стальная, Т.Г. Гаришвили // Современные методы в биохимии. - М.: Медицина. - 1977. С. 63 - 64.

Stal'naya I. D., Garishvili T. G. Methods for determining the diene conjugation of unsaturated higher fatty acids / I. D. Stal'naya, T. G. Garishvili / / Modern methods in biochemistry. - M.: Meditsina. - 1977. p. 63-64.

7. Стальная И.Д., Гаришвили Т.Г. Метод определения мало- 
нового диальдегида с помощью тиобарбитуровой кислоты // Современные методы в биохимии / Под ред. В.Н. Орехович. - Москва: Медицина, 1977. - С. 66 -68.

Stal'naya I. D., Garishvili T. G. Method for the determination of malondialdehyde using thiobarbituric acid // Modern methods in biochemistry / Edited by V. N. Orekhovich. - Moscow: Meditsina, 1977. - p. $66-68$.

8. Прохорова Т.М., Алексеев А.А. Изменение поведения и показателей билирубина у лабораторных крыс при хроническом токсическом гепатите // Вестник Бурятской сельскохозяйственной академии им. Филиппова. - 2020. - №1. - С 121-126. Prokhorova T. M., Alekseev A. A. Change in behavior and indicators of bilirubin in laboratory rats with chronic toxic hepatitis / / Bulletin of the Buryat Agricultural Academy. Filippova. - 2020. No. 1. - From 121-126.

9. Пудовкин Н.А., Салаутин В.В., Прохорова Т.М. Влияние различных стресс-факторов на свободнорадикальное окисление липидов и поведение белых крыс // Актуальные вопросы ветеринарной биологии. 2017, №3 (35). С. 3-7.

Pudovkin N. A., Salautin V. V., Prokhorova T. M. Influence of various stress factors on free-radical lipid oxidation and behavior of white rats. 2017 , No. 3 (35). pp. 3-7.

10. Поперечнева Т.Ю., Кутепова И.Ю. Пудовкин Н.А. Кутепов А.Ю. Физиологическое и токсическое влияние различных доз ДАФС-25 на антиоксидантную систему защиты организма белых крыс// Вопросы нормативно-правового регулирования ветеринарии, 2010, №4, С. 110-112.

Poperechneva T. Yu., Kutepova I. Yu. Pudovkin N. A. Kutepov A. Yu. Physiological and toxic effect of various doses of DAFS-25 on the antioxidant system of protection of the body of white rats/ / Voprosy normativno-pravovogo regulirovaniya veterinarii, 2010, No. 4, pp. 110-112

\section{НОВОСТИ•НОВОСТИ•НОВОСТИ•НОВОСТИ•}

\section{Раствор фукоидана ускоряет процесс заживления ожоговых ран у крыс}

Учеными Научно-исследовательского центра «Курчатовский институт» было проведено исследование антибактериальных свойств фукоидана, выделенного из бурых водорослей рода фукус («морской дуб»), произрастающих у побережья Баренцева моря. Сотрудники НИЦ выделили данное соединение при помощи обработки раствором этилового спирта и воздействия ультразвуком. Содержание в «морском дубе» фукоидана составило $10 \%$.

По мнению исследователей, выделенное соединение нетоксично и позволяет бороться с инфекциями, не нарушая естественную микрофлору организма. Фукоиданы являются перспективным компонентом для использования в медицине и пищевой промышленности. В частности, фукус показал себя как средство, сдерживающее рост раковых опухолей у животных.

Ранее группе ученых института совместно с сотрудниками Санкт-Петербургского НИИ скорой помощи имени Джанелидзе удалось в рамках экспериментального исследования выяснить, что процесс заживления ожоговых ран у крыс протекает интенсивнее при использовании препаратов, приготовленных из бактериальной целлюлозы, дополнительно пропитанной раствором фукоидана.

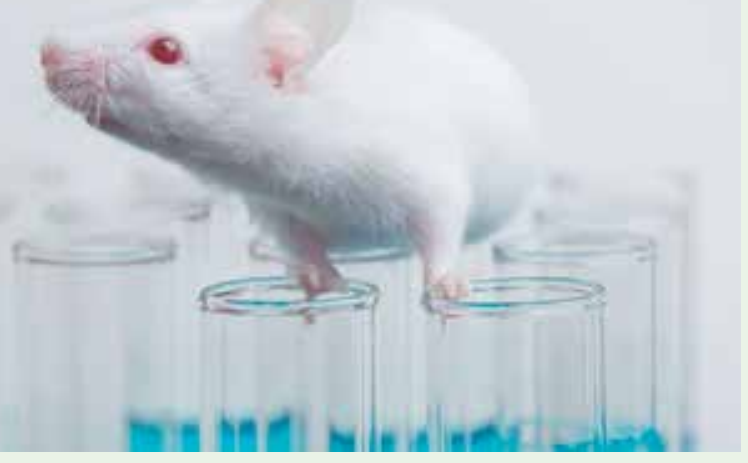

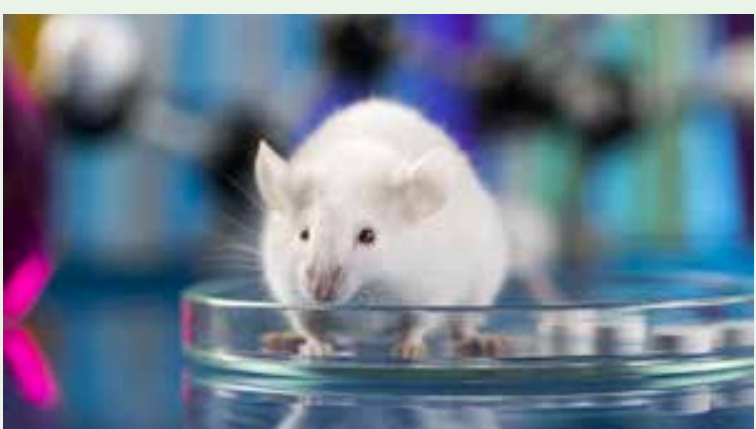

\section{Американские ученые разработали метод восстановления повреждений костей и кожи}

Ученые Университета штата Пенсильвания (США) разработали метод лечения травм при помощи 3D-печати твердых и мягких тканей одновременно. Исследователям удалось в течение нескольких минут запечатать отверстия в черепах и на коже подопытных крыс, используя 2 типа биочернил. Технология метода предполагает объединение двух способов биопечати: твердая ткань печатается методом экструзии, а мягкая - наносится в виде капель. Чернила твердой ткани состоят из коллагена, хитозана, наногидроксиапатита, ряда других соединений и главного компонента - мезенхимальных стволовых клеток, со временем превращающихся в костную ткань. Чернила мягких тканей печатаются слоями. Коллаген и фибриноген чередуются с соединениями, усиливающими склеивание и рост ткани, при этом между костью и кожей наносится барьерный слой, предотвращающий просачивание клеток кожи в кость.

На текущий момент ученые провели несколько десятков операций по восстановлению повреждений костей черепа и кожи крыс. В результате тесты показали, что мягкие ткани на месте «заплатки» восстанавливаются на 100\% в течение 4 недель, однако скорость восстановления костной ткани при такой комплексной печати несколько замедляется. По мнению исследователей, исправить ситуацию можно, добавив к биочернилам соединения, стимулирующие образование кровеносных сосудов. Это улучшит кровоток в кости и, соответственно, ускорит ее заживление.

В ближайшем будущем ученые планируют перейти к экспериментам на более крупных животных. 